the equinoxes. We have to consider, therefore, not me:ely the sidereal year, the time between which the earth is at one point with reference to the sun and a star, and the time when it is at that same point again; we have not mercly to consider the fact that this line of solstices, with its conjoined line of equinoxes, varies with regard to what is called the apse line, that is, the line joining the perihelion and aphelion points of the orbit, or the axis-major of the ellipse--but we get from this another year which is called the tropical year, which, like our mean time, is the one most used, because it brings the year into relation with our seasons. Now that we have got our mean time and know exactly how and why we have got it, we may express the sidereal year in mean time, and say that it consists of 365.256 solar days. The tropical year - the time which elapses between two successive passages through the vernal equinox-is shorter than the sidereal one, owing to the precession along the orbit of the equinoctial points, and consist of $365^{\circ} 242$ mean solar days, and the difference between the lengths of this and the sidereal year will of course give the annual amount of precession which takes place. Anomalistic year is the term applied to the period which elapses between two successive passages through the perihelion or aphelion points of the orbit ; and as these points have a forward motion along the orbit, this year is longer than the sidereal one, being $365^{\circ} 259$ mean solar days.

We may give the exact lengths of these years in days, hours, minutes, and seconds as follows :-

\begin{tabular}{llllllll} 
& & \multicolumn{4}{c}{ Mean solar time } \\
d. & h. m. & s. \\
Mean sidereal year $\ldots$ & $\ldots$ & $\ldots$ & 365 & 6 & 9 & $9 \cdot 6$ \\
Mean tropical year ... & $\ldots$ & $\ldots$ & 365 & 5 & 48 & $46 \cdot 054440$ \\
Mean anomalistic year & $\ldots$ & $\ldots$ & 365 & 6 & $\mathbf{1 3}$ & $49 \cdot 3$
\end{tabular}

The Movcments of the Earth are so important to us, and so interesting in themselves, that it is not possible in six lectures to exhaust all that may be said about them or learned from them. I trust however that I have left no point of the first importance untouched. The moral of these lectures is that astronomy has appealed to physics, and has not appealed in vain, for the demonstration of the physical reality of the movements in question.

J. NORMAN LOCKYER

\section{THE FRENCH ASSOCIATION FOR THE PROGRESS OF SCIENCE}

THIS Association began its meetings at Blois on September 3 . The financial situation of the Association is very prosperous indeed; the capital has amounted to 20,0002 . ; but the sum spent in scientific researches amounts to only $300 \%$.

The President of the Association for this year is M. Bouquet de la Grye, and his inaugural address consisted of a sketch of the history of oceanic hydrography. He dealt with the difficulty of the determinations made on the bottom of the sea, and insisted on a new idea of his own. He believes that the level of the sea presents considerable variations owing to the quantity of salt contained in the water. He says that the level of the Mediter ranean ought not to be so high as the level of the ocean owing to the greater quantity of salt and consequently of density. A diminution of temperature produces the same effects as enlarging the density; so an increase of the temperature of the German Ocean would produce a flood on the Belgian, Dutch, German, and French coasts, and bring the sea to Paris.

Dr. Grimaux, a pupil of the late M. Wurtz, delivered a speech on the illustrions Academicians who have died during the past year, among whom Dumas and Wurtz have unquestionably the foremost place.

It is probable that this year the long-hoped-for fusion with the Association Scientifique de France, established by Leverrier, and presided over by Milne-Edwards, will take place, and the two Associations amalgamated in one will take a new start.

One of the principal objects of the present sitting has been the examination of the Thenay geological strata, wherc Abbé Bourgeois thinks he has discovered Tcrtiary man. The principal French geologists have arrived in Blois for the excursions. There arc very few foreigners at the meeting.

TRAINING IN NAVAL ARCHITECTURE ${ }^{1}$

$\mathrm{A}^{\mathrm{T}}$ Govan, the great shipbuilding suburb of Glasgow, on the 4th inst., Prof. F. Elgar, of Glasgow University, addressed the students attending the Science and Art Classes upon the I Communicated by Prof. Elgar. above subject. In the course of his address Prof. EIgar said :-

"All of the students wh) attend the classes in naval architecture and engineering here are probably much better acquainted with the practical and experimental aspects of the work they are engaged in than they are with the science which underlies it; and their present object is the very vital and praiseworthy one of acquiring such scientific and technical knowledge as will enable them to apply sound principles to the performance of their work, and to assist them in dealing intelligently and successfully with the many difficult and novel questions which are constantly obstructing and puzzling them. There are no branches of mechanical art in which sound scientific knowledge is more essential and useful, or in which it is more necessary for theory and practice to go hand-in-hand together, than those of shipbuilding and engineering. A modern steamer is so complex a machine that no attempts to construct one without calling in the aid of science in some form-either directly or by copying what others have learned by it to do-could possibly end in anything but disastrous failure. Try to imagine a man who had never heard or read of any of the teachings of science attempting to construct a modern steamship-a man who did not know even of the proposition, said to have been demonstrated by Archimedes, that a floating body displaces a volume of water whose weight is equal to its own weight; and who was ignorant of the wonderful discoveries that have been made of the laws by which heat generated by the combustion of coal is converted into mechanical work through the agencies of the boiler and steam-engine. It only requires to state the matter in this bald form in order to show how hopelessly impossible and absurd such an attempt would be, and how vitally dependent shipbuilding and engineering are upon the past achievements and present teachings of science. On the other hand, the highest scientific talent the world has yet produced would be equally unable to arrive at a successful result simply by means of pure theory, however advanced, and by strict a priori methods. The course you are pursuing, and which I trust you will not depart from, is the one best calculated to insure for you the greatest success in your work and advancement in your various positions in life; and as in the daily practice of your profession you are perforce kept well abreast of the practical and experimental sides of your work I would now urge you, in the strongest manner possible, to cultivate most diligently and thoroughly a knowledge of the science and of those natural laws upon which the efficiency and success of your efforts depend. Whatever may be the character of your daily work, whether you are employed as engineers, draughtsmen, or mechanics-and I am very pleased to know that there are working mechanics who attend these classes, and who are among the most earnest, intelligent, and capable of the students-never rest satisfied till you know the meaning of all that you do and why you do it. Do not be content with merely learning methods of setting off work and performing calculations, or with copying processes you may have seen others employ. The man who merely does as he sees others do, without very well comprehending why they do it, and who works strictly by rule and line, looking to custom as the supreme authority, will never improve or advance himself, nor be of much real use in such times as these; nor will he find much interest in his work.

$$
\begin{aligned}
& \text { 'Custom, which all mankind to slavery brings, } \\
& \text { That dull excuse for doing silly things.' }
\end{aligned}
$$

Never look to custom as being a sufficient authority for anything, however respectable its antiquity may have made it; but be determined to understand for yourselves whether or not it is based upon sound and intelligible principles. Although we are now meeting under the auspices of the Young Men's Christian Association, I can safely recommend you to indulge freely a spirit of scepticism in this particular department of the Association's work. The region of science and of the pure intellect is not one in which you should be content to accept the mere authority of any one as final, or to test any question except by the standard of your? own reason. Do not be too eager to believe that anything you are told is correct until you are able to prove it for yoursclves, and till you no longer feel any ignorance or doubt in the matter. The necessity for combining wide scientific knowledge and sound theory with practical experience, in the carrying on of shipbuilding and enginecring operations, is daily becoming more and more pressing. If you tried to avoid it you could not. In this age of keen competition and rapid development, increasing demands are made upon all who are engaged in these important 
industries. Every success that is achieved by the most advanced and sensational productions creates a demand for still further progress ; and in meeting these demands, in the future, the race will he to the swift and the battle to the strong. The speed and the strength that you require in order to enable you to hold your own in this contest are speed and strength of intellect. In other words, you require your intelligence to be cultivated and well informed, and to be made prompt and active, by mcans of scientific culture ; and it is necessary for you to acquire such a firm and comprehensive grasp of sound theoretical principles as will enable you to rely safely upon your own powers of judgment, and to act in difficult cases with certainty and precision. Not only does modern competition ever demand more from you in the way of technical lnowledge, skill, and resource, but it also shortens the time at your disposal for supplying it. The huge and complicated engineering structures of the present day, such as are constructed in this district, have to be completed in as short a time as the much simpler and smaller ones of a generation ago. You have thus not only much more to think about in building a ship, and problems of greater number and difficulty to solve than used to be the case, but you have only the same time in which to do it all. You cannot afford to delay the progress of construction for the ptirpose of trying experiments or brooding over any difficulties you may meet with. It is necessary to decide promptly each question as it arises, and you have to qualify yourselves for doing that. The naval architect and engincer of the present day requires to supplement his practical knowledge by a close and systematic study of various branches of science. An enumeration of some of the chief of them will be sufficient to show how great are the demands thus made upon him. There are the laws upon which the flotation and stability of ships, and their behaviour among waves, depend; those which determine the structural strength of a ressel, and its relation to the forces which may be brought to bear upon her by her own weight and that of her cargo, when she is floating upon a changing wave-surface ; the difficult problems connected with the resistance of a ship to motion through the water, the power requisite to drive her at a given speed, and the manner in which this is affected by her outward form and proportions. Then there is the wide field of thermal science, and its application to the means by which the conversion of heat into mechanical work is effecter through the agencics of the boilers, cylinders, condenser, and mcchanism of the engines; together with the action of the propeller, and the principles upon which its efficiency depends. No man has ever yet succeeded in completely mastering these difficult and complicated problems; and it is perhaps not possible for many of you to advance very far towards their solution. Still it must be borne in mind that it is only by studying the sciences which bear upon them that any real or substantial progress can be effected; and although finality may be unattainable, great advances are possible, and are constantly being made. Hardly a year passes without something considerable being done to improve our knowledge of those natural laws upon which the safety and efficiency of ships at sea depend. There is probably no district in this country which has benefited more in the past than Govan by scientific progress and great mechanical skill in shipbuilding and engineering, or whose prosperity in the future is more dependent upon it. Govan has been placed among the foremost of shipbuilding communities by means of great scientific and practical talent, industry, and enterprise ; and it rests with many whom I now see before me to maintain it in the honourable and distinguished position to which it has been raised. The names of Napier and Elder, not to mention others, are alone sufficient to give prestige to any engincering locality ; and they insure for Govan a high place in all future records of scientific, mechanical, and industrial progress. Upon you rests the responsibility of worthily walking in the footsteps of those and others among your distinguished men, and of striving to keep erect in this district the noble edifice they have reared."

\section{SOCIETIES AND ACADEMIES PARIS}

Academy of Sciences, September I.-M. Rolland, President, in the chair.-Some remarks on the subject of the theory of the figure of the planets, by M. F. Tisserand. The author's calculations and estimates of their present form are based on the assumption that the celestial bodies were originally in the fluid state, subject only to the mutual attraction of their constituent elements, and endowed with a rotatory movement with very slight angular velocity. Their outer surface would thus be somewhat that of a revolving ellipsoid.-Researches on the general development of vegetation in an annual plant : functions of the hydrocarbon elements, by MM. Berthelot and André. - Note on the general resolution of the linear equation in matrices of any order, by Prof. Sylvester. -Remarks on the attempts made at various times to solve the problem of aërial navigation, by $\mathrm{M}$. Laussedat. The author supplies a rapid sketch of the progress of aërostatics in connection with the Commission lately appointed by the Academy to examine the claims of priority of various inventors. He considers that Gencral Mensnier was the first to introduce the elongated shape of the balloon, the screw as the propelling agent, and the principle of the "ballonnet" or air-bag, rediscovered by M. Dupuy de Lôme. M. Conté is credited with great improvements in the construction of spherical balloons, and M. Alcan is stated to have anticipated M. H. Giffard by several years in the application of steam to aërial navigation.-Comparison between the coloured electro-chemical and thermal rings of Nobili and others, by M. C. Decharme.-Observations of the planet 240 discovered at the Observatory of Marseilles on August 27, r884, by M. Borrelly.-Determination of the wavelengths of the chief rays and bands of the infra-red solar spectrum, by M. Henri Becquerel. Tabulated results are given for the chief bands in millionths of millimetres.--Remarks on the formation and development of the nervous cellules in the spinal marrow of mammals, by M. W. Vignal.-Note on the recent luminous phenomena observed around the sun in Switzerland (second communication), by M. F. A. Forel. A second trip to the Alps, undertaken towards the end of August, enables the author to confirm and complete the details already communicated to the Acadcmy. Aeronauts are invited to study some of these light-effects, and especially the red corona round the sun, scarcely perceptible from the plains and low elevations, but perfectly visible at altitudes of from 3000 to 6000 feet above the sea-level.--Account of the optical telegraph recently cstablished between the islands of Mauritius and Réunion, by M. Bridet. The telegraph set up on Lacroix Peak in Rémion and Vert Peak in Mauritius was completed on the night of July $12-13$, when messages were freely exchanged between the two islands.

\section{CONTENTS}

PAGE

Descriptive Mineralogy $\cdot \dot{0} \dot{j} \dot{\mathrm{G}} \cdot \dot{\mathrm{R}} \dot{\mathrm{S}} \quad 46 \mathrm{I}$ The Mosses of North America. By J. G. Baker, F.R.S, $46 \mathrm{I}$ Letters to the Editor :-

The Diffusion of Species.-The Duke of Argyl1. Meteor- Moon- and ISun-Shine--Prof. C. Piazzi Smyth, Astronomer-Royal for Scotland

Pons' Comet-Pink Glow.-A. S. Atkinson Alternation of Generations in Salpa,-R.N.Goodman Forked Lightning.-Rev. Dr. C. Michie Smith Sun-Glows.-Robert Leslie

Fireballs.--Wm, White

Deep-Sea Corals.-Prof. P. Martin Duncan, F. R. S. Iridescent I, unar Halos.-T. H. Potts

Sextants.--T. W. Baker

Electrical Rainbow.-R. S. Newall, F.R.S.

Rainbow on Spray.-G. H.

Circular Rainbow seen from a Hill-top.-W. Goodwin

Intelligence in Frogs.-B. W. S

The Temperature of the Solar Surface. By Capt. $J$. Ericsson. (Illustrated).

The British Association :-

Section E-Geography-Opening Address by General Sir J. H. Lefroy, R.A., C.B., K. C.M.G., F.R.S. F.S.A., V.P. K.G.S., President of the Section Section G-Mechanical Science-Opening Address by Sir F. J. Bramwell, F.R.S., V.P.Inst.C.E. President of the Section

Notes

Geographical Notes

Our Astronomical Column :-

Variable Stars

Comet $1884 b$ (Barnard)

The Movements of the Eatth, VI. By J. Norman Lockyer, F.R.S. (Illustrated) .

The French Association for the Progress of Science Training in Naval Architecture. By Prof. Elgar . Societies and Academies . . . . . . . . .
462

462 463 463 463 463 464 464 464 464 464 464 465

472 476 